\title{
A water-energy balance application with adaptations to a brazilian water supply
}

\section{system}

\author{
Aplicação de balanço hidroenergético com adaptações para um sistema de distribuição de água no \\ Brasil
}

Aplicación de balance hidroenergético con adaptaciones para un sistema de distribución de agua en

Brasil

Received: 08/03/2021 | Reviewed: 08/08/2021 | Accept: 08/10/2021 | Published: 08/14/2021

\begin{abstract}
According to the Alliance to Save Energy, between $2 \%$ and $3 \%$ of the total electric energy consumed in the world is used for water pumping in supply systems, with the consumption reduction potential through energy efficiency and conservation measures being estimated at $25 \%$. In Brazil, the water supply sector corresponds to $2.6 \%$ of the total energy consumed in the country, with pumping systems being responsible for over $90 \%$ of the total energy consumption. It is extremely common to find supersized facilities with pump motor sets operating outside their ideal points, with it being a common practice to perform flow and pressure control through the installation of valves. The use of reducing valves inserts unnecessary pressure drops into the hydraulic system, increasing energy consumption. The objective of this work is to present an energy balance of a study sector of the Autonomous Water and Sewage Service (AWSS) of a municipality in the south of Minas Gerais, Brazil, aiming to elucidate the electric energy consumption of the system and where the reduction in such consumption may occur. For this, we measured data such as the efficiency of the pump motor sets, calculated performance indicators and water loss indices, and applied the energy balance adapted. This work presents an application of a water-energy balance with adaptations to a Brazilian water supply system, under the perspective of the energy efficiency in lift station pump motor sets.
\end{abstract}

Keywords: Water, Energy; Water-energy balance; Energy efficiency; Water supply system.

\section{Resumo}

De acordo com a Aliança para Economia de Energia, entre 2\% e 3\% do total da energia elétrica consumida no mundo é destinada ao bombeamento de água nos sistemas de abastecimento, sendo o potencial de redução do consumo por meio de medidas de eficiência e conservação energética estimado em $25 \%$. No Brasil, o setor de abastecimento de água corresponde a $2,6 \%$ do total de energia consumida no país, sendo os sistemas de bombeamento responsáveis por mais de $90 \%$ do consumo total de energia. É extremamente comum encontrar instalações superdimensionadas com conjuntos de motobombas operando fora de seus pontos ideais, sendo prática comum realizar o controle de vazão e pressão através da instalação de válvulas. O uso de válvulas redutoras insere quedas de pressão desnecessárias no sistema hidráulico, aumentando o consumo de energia. O objetivo deste trabalho é apresentar um balanço energético de um setor de estudos do Serviço Autônomo de Água e Esgoto (SAAE) de um município do sul de Minas Gerais, Brasil, visando elucidar o consumo de energia elétrica do sistema e onde o redução desse consumo pode ocorrer. Para isso, medimos dados como a eficiência dos conjuntos de motobombas, calculamos indicadores de desempenho e índices de perdas de água, e aplicamos o balanço energético adaptado. Este trabalho apresenta a aplicação de um balanço hídrico-energético com adaptações a um sistema de abastecimento de água brasileiro, sob a perspectiva da eficiência energética em conjuntos motobombas de estação elevatória.

Palavras-chave: Água; Energia; Balanço hidroenergético; Eficiência energética; Distribuição de água. 


\section{Resumen}

Según la Alianza para el Ahorro de Energía, entre el 2\% y el 3\% del total de energía eléctrica consumida en el mundo se destina al bombeo de agua en los sistemas de abastecimiento, estimándose en un $25 \%$ el potencial de reducción del consumo mediante medidas de eficiencia y conservación energética. En Brasil, el sector de abastecimiento de agua corresponde al 2,6\% del total de energía consumida en el país, siendo los sistemas de bombeo responsables de más del $90 \%$ del consumo total de energía. Es muy común encontrar instalaciones de gran tamaño con conjuntos de motores de bomba operando fuera de sus puntos ideales, siendo una práctica común realizar el control de flujo y presión mediante la instalación de válvulas. El uso de válvulas reductoras introduce caídas de presión innecesarias en el sistema hidráulico, lo que aumenta el consumo de energía. El objetivo de este trabajo es presentar un balance energético de un sector de estudio del Servicio Autónomo de Agua y Alcantarillado (SAAA) de un municipio del sur de Minas Gerais, Brasil, con el objetivo de dilucidar el consumo de energía eléctrica del sistema y donde puede producirse una reducción de dicho consumo. Para ello, medimos datos como la eficiencia de los grupos motobomba, calculamos indicadores de rendimiento e índices de pérdida de agua, y aplicamos el balance energético adaptado. Este trabajo presenta una aplicación de un balance agua-energía con adaptaciones a un sistema de abastecimiento de agua brasileño, bajo la perspectiva de la eficiencia energética en grupos motobomba de estaciones elevadoras.

Palabras clave: Agua; Energía; Balance Hidro-energético; Eficiencia energética; Distribución de agua.

\section{Introduction}

Water is an essential asset of extreme value and importance in the lives of human beings. With the growth of the world population and the scarcity of the natural resource of water, it becomes necessary to direct preventive actions that may optimize its use, thus achieving sustainability (Chini \& Stillwell, 2018; Razmjoo et al., 2020; Sgroi et al. 2018; Cantele et al. 2018; Aznar-Sánchez et al., 2018; Baleta et al.2019; Bieber et.al.2018; Lee et al., 2021). Currently, there are many studies related to energy generation through water; however, few analyze and highlight the environmental impacts caused by water usage.

Water supply is a primary element of an urban system (Krueger et al, 2020). Due to the fast urbanization and water scarcity, keeping a water supply stable and with quality has become a challenge for many cities, with large amounts of water being lost from distribution system pipes (Mamade et al., 2018a). Water leakage is not only a waste of water resources but also has great socioeconomic costs. (Song et al 2018)

The operation of the water supply system consists of establishing operational rules with a sequence of maneuvers carried out with the pump motor sets and valves that are conducted by trial and error in most situations. According to Filho (1990), to define a better operational rule for a water supply system, some basic conditions are necessary, such as the clear definition of the objectives to be achieved, the knowledge of the system topography and of the hydraulic and mechanic characteristics of the elements that compose it, the knowledge of consumption prediction data, and the availability of mathematical models.

For the most part, the efficiency improvement of a water distribution system is an option with lower cost than the construction or reform of a water supply infrastructure (Britton et al., 2013). The water consumption stemming from water collection, treatment, and adduction implies high costs. (Ahopelto \& Vahala 2020). Several factors contribute to the energy losses in the water supply sector, such as inefficient pumping stations and operations, inappropriate projects, facilities, and maintenance, old piping, network bottlenecks, and excessive pressures, among other factors (Coelho \& Andrade-Campos, 2014; Luna et al.;2018; Oikonomou \& Parvania, 2018)

According to Rodrigues (2012), the activities implemented to save energy and water may have a higher impact if they are planned jointly, seeking the integration of the water and energy resource management with the goals of reducing environmental impacts, lowering operational costs, and encouraging the efficient use of resources.

The report by ABES (2013) demonstrates the synergy in the actions for water loss reduction and energy efficiency. When there is a drop in water losses, there is consequently also a reduction in the need to produce water, thus saving in energy consumption and reducing the final costs (Mamade et al., 2018b). 
According to ABES (2013), for each $R \$ 1.00$ spent on energy conservation, an investment of $R \$ 8.00$ in the generation is avoided. As reported by Mutikanga; Sharma; Vairavamooethy (2009), sophisticated leakage detection equipment alone is not enough to lower water losses in developing countries. In addition, a holistic approach to the problem is necessary.

Mamade et al. (2017) proposed a new energy balance methodology and performance indicators to evaluate power efficiency in water supply systems. This energy efficiency evaluation encompasses three steps: The first step is the characterization of the system and the collection of data related to the physical, hydraulic, mechanical, and electric assets. The second step is to calculate the energy balance components, and the third step is the calculation and analysis of performance indicators to understand the efficiency improvement opportunities.

This paper has the objective of studying and analyzing the application of the water-energy balance, a methodology by Mamade et al. (2017), with adaptations to a sector of the water distribution network of a municipality in the south of the state of Minas Gerais, Brazil.

\section{Methodology}

\subsection{System characterization}

A city studied in the south of the state of Minas Gerais, Brazil, has a water supply system with sectorization characteristics. According to the Brazilian National Waters Agency (ANA, 2018), the urban water supply system of the city collects water, for the most part, from the Antas River, an affluent of the Itaim River, belonging to the Sapucaí sub-basin. Another portion of the water is collected from the Córrego Rio do Peixe.

The mean volume of water collected and treated is approximately seven million liters of water per day. The treatment of the waters collected from the Rio das Antas and the Córrego Rio do Peixe is carried out in the same water treatment plant (WTP), and they are mixed in the same water main network.

\subsection{Sector of study and interest}

The studied sector was chosen for being an isolated sector for which it is possible to know the inputs and outputs of the system. This sector encompasses part of the area supplied by reservoirs R3 and R4 as identified in the Autonomous Water and Sewage Service (AWSS) and contemplates the neighborhoods of Água Branca, Vale das Montanhas, Vale do Sol, Vila Mariana, and Vale das Rosas.

The sector begins in reservoir R3 (maximum capacity of $400 \mathrm{~m}^{3}$ ), in which part of the water is pumped to R4 who comprises two reservoirs, one of which is rectangular with a capacity for $100 \mathrm{~m}^{3}$ of water. This rectangular reservoir is connected to a tubular reservoir with a capacity for $50 \mathrm{~m}^{3}$ of water that only starts to fill after the rectangular one is completely supplied

In reservoir R3, two equal pump motor sets are installed to perform the lifting of the water through two isolated pipelines. One such system pumps and supplies reservoir R4 directly $(150 \mathrm{~mm}$ diameter pipe, altitude difference of approximately 42 meters between them, and a $1.41 \mathrm{~km}$ distance following the pipeline path). The other system supplies three reservoirs that are not part of the sector of interest and the remaining flow in this pipeline follows to reservoir R4.

The rectangular reservoir has a usable volume of only $69.6 \mathrm{~m}^{3}$, against $100 \mathrm{~m}^{3}$ of its total capacity. This reservoir has a buoy level-control system, transferring the water supply to the cylindrical reservoir when the first is supplied. The cylindrical reservoir has $3.20 \mathrm{~m}$ of diameter and a total water-level height of $6.20 \mathrm{~m}$. The usable-level height was defined by the position of the maximum-level sensor $\left(5.92 \mathrm{~m}\right.$ ), resulting in a total usable volume of $47.61 \mathrm{~m}^{3}$, against $50 \mathrm{~m}^{3}$ of its total capacity. This reservoir has a level-monitoring system to trigger the pump-motor sets.

Monitoring is only of the full or empty levels. Before reaching the neighborhood of Vila Mariana, there are two 
reservoirs also supplied by the R4; however, the water in these reservoirs is only used on high-consumption days, especially during weekends. On the data collection week, the check valve that isolates such reservoirs remained closed, isolating this part of the sector whose diagram can be seen in Figure 1.

Figure 1. Diagram of the studied Sector.

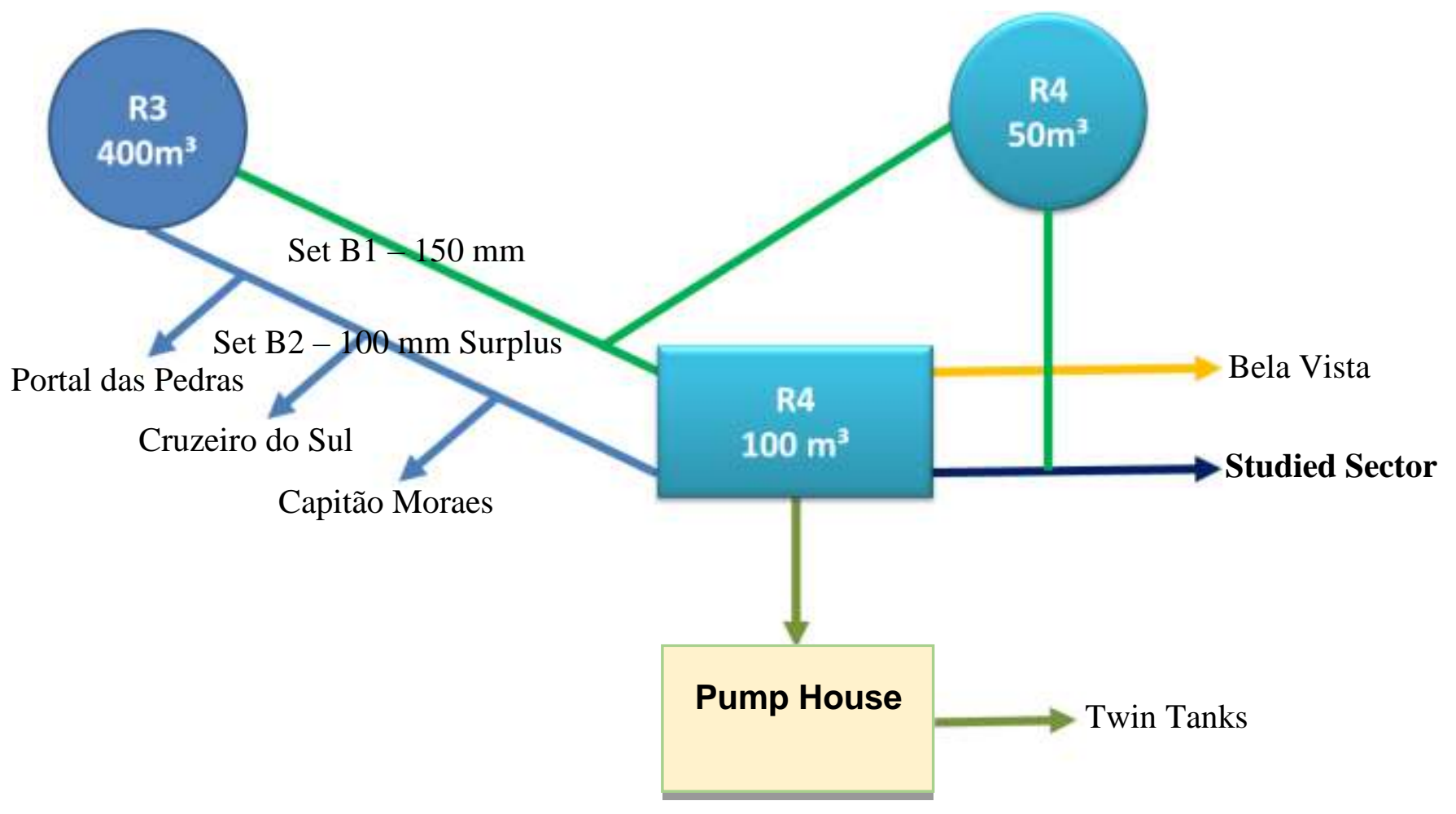

Source: Adapted from Andrade (2016).

\subsection{Field tests}

The acquisition of internal reports from the AWSS was through field visits. We collected data on the consumption of water, energy, and reagents, as well as the diameters of the studied pipelines and a map of the network, among other information was collected during seven consecutive days (October 8th to 14th, 2014). Table 1 presents the characteristics of pumps 1 and 2 .

Table 1. Rated data of pumps 1 and 2.

\section{Pump 1}

\section{Model / Series}

Rated flow $\left(\mathbf{m}^{3} / \mathbf{h}\right)$

Rotor $(\mathbf{m m})$

TMH (mwc)
ETA $5020 / 231800$

40

196

72

Source: Authors.

\section{Pump 2}

ETA $5020 / 231801$

40

196

72

Table 2 demonstrates the rated data of the motors. 
Table 2. Rated data of the motors.

$\begin{array}{ccc}\text { Manufacturer } & \text { Motor 1 } & \text { Motor 2 } \\ \text { Model / Series } & \text { WEG } & \text { WEG } \\ \text { Rated output (hp) } & \text { 160M / CC62140 } & \text { 160M / CC62137 } \\ \text { Rated output (kW) } & 25 & 25 \\ \text { Frequency (Hz) } & 18.5 & 18.5 \\ \text { Rated speed (rpm) } & 60 & 60 \\ \text { Power factor } & 3525 & 3525 \\ \text { Rated efficiency } & 0.88 & 0.88 \\ \text { Service factor } & 89.6 & 89.6 \\ & 1.15 & 1.15\end{array}$

The methodology used in this paper is based on Mamade et al. (2017), where researchers proposed a new energy balance methodology and performance indicators to evaluate power efficiency in water supply systems. This energy efficiency evaluation encompasses three steps: Characterization of the system, calculate the energy balance components and calculation and analysis of performance indicators to understand the efficiency improvement opportunities.

A simplified assessment, which is used the most when the provider lacks hydraulic models, requires minimal data and may be applied at the system level, providing a general view of the main energy consumption components. A complete evaluation requires a calibrated hydraulic system and a network model, providing a detailed assessment of the energy consumption at all components of the balance. The calculations may be carried out using the simulation through the EPANET® software.

The complete evaluation of critical analysis areas requires calculating the complete energy balance. The supplied hydraulic models must be properly calibrated (for example, distribution of demand and reservoirs) using the pressure and flow measurements along the network. We used the hydraulic model of the EPANET elaborated by Goulart (2015) and the algorithm developed by CERIS, Instituto Superior Técnico, Universidade de Lisboa, Portugal, Urban Water Unit, National Civil Engineering Laboratory, Hydraulics and Environment Department, with software iPerdas.

The selected area belongs to only a part of the chosen city. The application sector of the complete energy balance starts from reservoir R4 since the simplified one was applied between reservoirs R3 and R4. In the studied sector, there are approximately 1,652 water consumers. The water supply of this area supplies 413 connections at a daily mean of 263.557 $\mathrm{m}^{3} / \mathrm{day}$, without differentiating the seasonal water consumption behavior.

Upon calculating the energy balance, an audit must be performed that allows calculating the energy consumed in the system. This may be acquired through the integration of the energy equation. The energy balance scheme proposed by Mamade et al. (2017) is demonstrated in Table 3. 
Table 3. Energy Balance based on the Methodology by Mamade (2017).

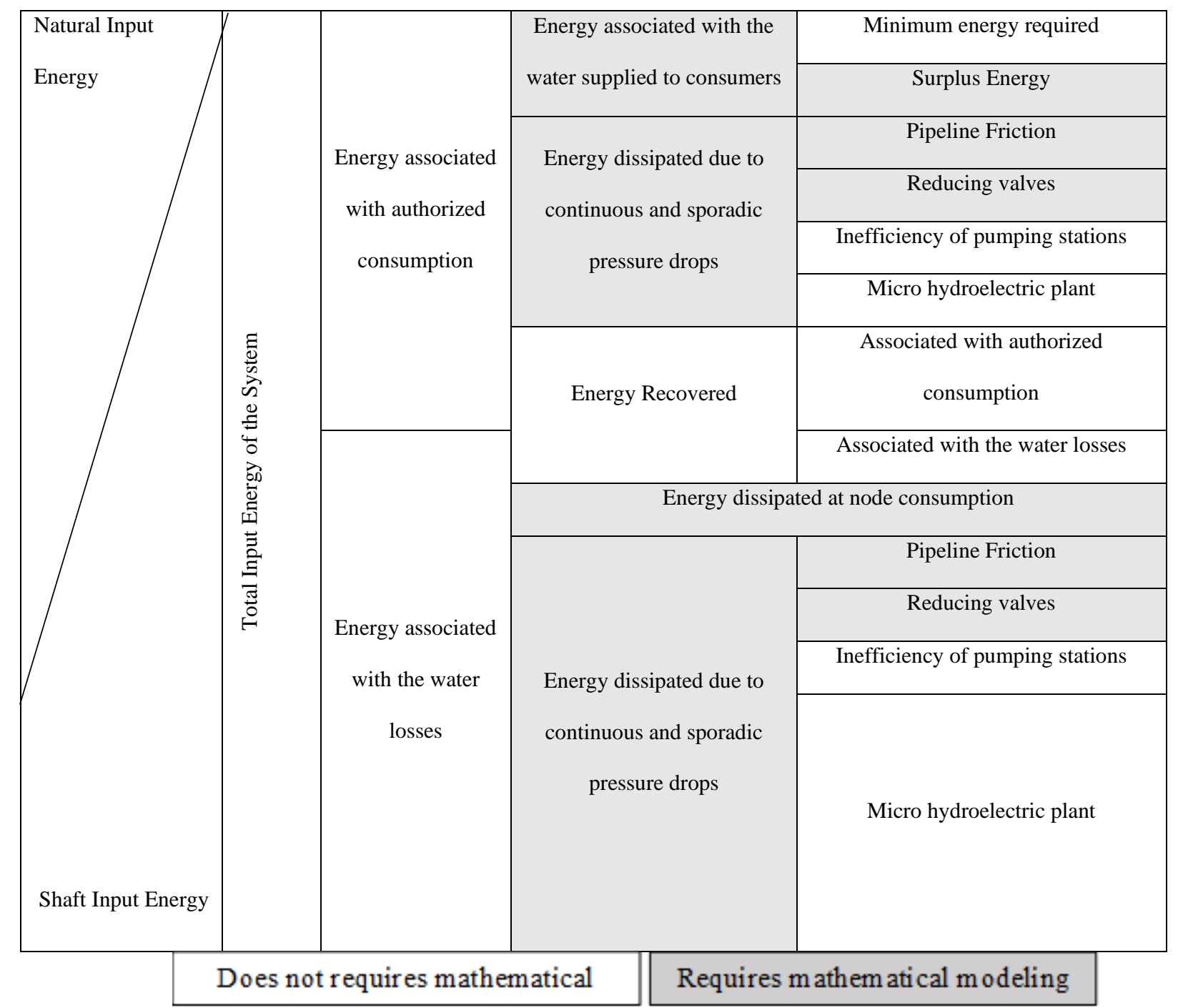

Source: Adapted from Mamade et al. (2017).

Information from the water balances by Andrade (2016) is used in this process to separate the energy associated with water consumption and the water losses, providing an intuitive perception of the efficiency improvements that may be achieved by reducing water losses (real and apparent losses). Consequently, the percentage of energy associated with water loss is equal to the percentage of water losses in the system, assuming that the losses are uniformly distributed through the system for the simplified and detailed evaluation.

In the simplified evaluation, the calculation of the items is restricted to the blank parts of Table 3, while the complete assessment includes all components. Each component of the energy balance scheme must be calculated relative to a reference level.

It is recommended that the node with the lowest elevation be adopted as the reference so that, upon comparing different systems, all calculations refer to the same reference level. The simplified evaluation was used in this work; all equations were adapted due to the limits, layout, and main assets (pipes, tanks, pumping stations) of the studied system.

Figure 02 illustrates the concepts necessary to calculate the energy balance components for the lifting and distribution systems. In this example, the pumping system lifts the water and delivers it to a reservoir that supplies the water to a specific network sector. 
Figure 2. Schematic representation of the different concepts necessary to calculate the energy balance components for the lifting and distribution systems.

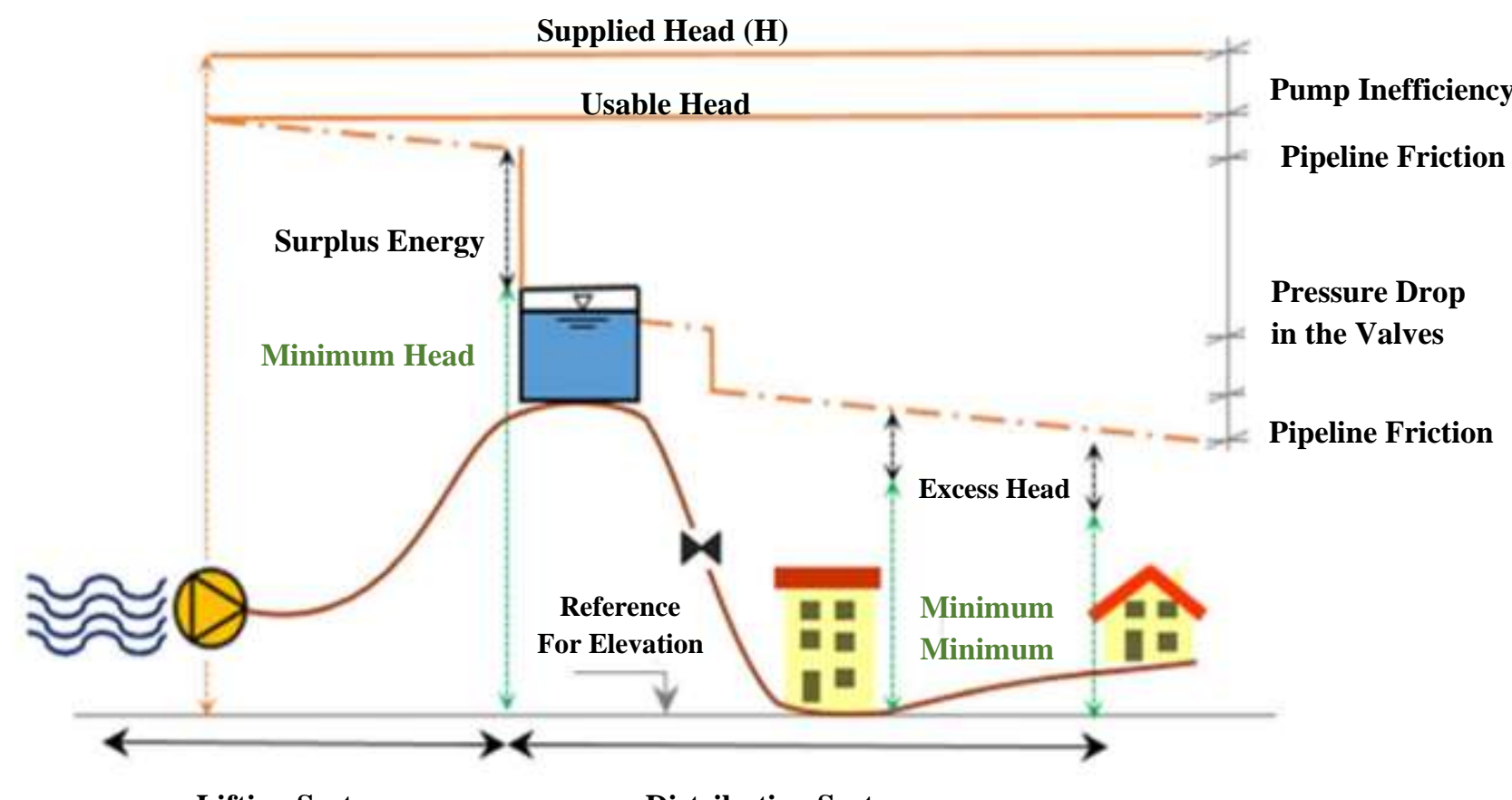

Lifting System

Distribution System

Source: Adapted from Mamade et al. (2017).

According to Mamade et al. (2017), the parcel of the total input energy of the system has two main components, the first being the shaft input energy, which refers to the energy provided by the lift station (R3). Equation 01 exemplifies the calculation of this component.

$$
\mathrm{E}_{\mathrm{Sl}}=\mathrm{B}+\mathrm{\gamma}^{*}\left(\forall_{\mathrm{p}}^{*}\left(\mathrm{~h}_{\mathrm{p}}-\mathrm{z}_{0}\right)\right) * \alpha
$$

Where:

- $\quad \forall_{\mathrm{p}}$ is the annual volume of pumped water $\left(\mathrm{m}^{3}\right)$;

- $\quad B$ is the annual electric energy consumption value of lift station R3;

- $\quad \mathrm{hp}$ is the head (m) downstream from the pump;

- $\quad \mathrm{z}_{0}$ is the reference elevation $(\mathrm{m})$;

- $\quad \gamma$ is the specific weight of the water $\left(\mathrm{N} / \mathrm{m}^{3}\right)$;

- $\alpha$ is the conversion factor from Ws to $\mathrm{kWh}, 1 /(1000 \times 3600)=2.78 \times 10^{-7}$.

The second component is the natural input energy, which refers to the gravitational energy provided by the reservoirs. Equation 02 describes how the natural input energy is calculated. 


$$
\mathrm{E}_{\mathrm{N}}=\gamma^{*}\left(\forall_{\mathrm{r}}^{*}\left(\mathrm{H}_{\mathrm{r}}-\mathrm{z}_{0}\right)\right) * \alpha
$$

Where:

- $\quad \mathrm{z}_{0}$ is the reference elevation $(\mathrm{m})$;

- $\quad \gamma$ is the specific weight of the water $\left(\mathrm{N} / \mathrm{m}^{3}\right)$;

- $\quad \mathrm{H}_{\mathrm{r}}$ is the reservoir head $(\mathrm{m})$;

- $\quad \forall_{\mathrm{r}}$ is the annual volume supplied by the reservoir/tank $\left(\mathrm{m}^{3}\right)$;

- $\quad \alpha$ is the conversion factor from Ws to $\mathrm{kWh}, 1 /(1000 \times 3600)=2.78 \times 10-7$;

To calculate the total input energy, one may use Equation 03.

$$
\mathrm{E}_{\mathrm{TOT}}=\mathrm{E}_{\mathrm{SI}}+\mathrm{E}_{\mathrm{N}}
$$

Of the total input energy (natural and shaft), one part is used to supply the authorized consumption (EAC), and the other is associated with water losses (EWL), as related in the water valances (LAMBERT; HIRNER, 2000, apud MAMADE et al., 2017). Such components are calculated through Equations 04 and 05.

$$
\begin{aligned}
& \mathrm{E}_{\mathrm{AC}}=\mathrm{E}_{\mathrm{TOT}} * \frac{\forall_{\mathrm{AC}}}{\forall_{\mathrm{TOT}}} \\
& \mathrm{E}_{\mathrm{WL}}=\mathrm{E}_{\mathrm{TOT}}-\mathrm{E}_{\mathrm{AC}}
\end{aligned}
$$

Where:

- $\quad \forall \mathrm{AC}$ is the annual authorized consumption $\left(\mathrm{m}^{3}\right)$;

- $\quad \forall$ тот is the annual input volume of the system $\left(\mathrm{m}^{3}\right)$.

Of the total energy associated with the authorized consumption, one part is the minimum energy necessary to supply the consumers. This component is calculated through Equation 06.

$$
\mathrm{E}_{\mathrm{MIN}}=\gamma^{*}\left(\forall_{\mathrm{AC}} *\left(\mathrm{z}_{\mathrm{CM}}+\mathrm{p}_{\mathrm{REQ}}-\mathrm{z}_{0}\right)\right) * \alpha
$$

Where:

- $\quad \forall \mathrm{AC}$ is the annual authorized consumption $\left(\mathrm{m}^{3}\right)$;

- $\quad \mathrm{zCM}$ is the center of mass of the consumption;

- $\mathrm{p}_{\mathrm{REQ}}$ is the minimum pressure required $(\mathrm{m})$ at the analysis area. 
In calculating the minimum energy in the simplified evaluation ( $\mathrm{E}_{\mathrm{MIN}}$ ), the system must be divided into homogenous areas according to the pressure and consumption, in which the annual authorized consumption must be known. Hence, the center of mass of the consumption must be estimated, and a minimum required pressure must also be assumed for the entire area.

This pressure value depends on the area characteristics (size, type of residences) and must also take into consideration the values required by NBR Technical Standard No. 12218/1994. The supplied pressure may be higher than the required pressure, creating an energy surplus in the system ( $\left.E_{S U R}\right)$. Equation 07 exemplifies the calculation of this surplus energy.

$$
\mathrm{E}_{\mathrm{SUR}}=\gamma^{*}\left(\sum_{\mathrm{n}=1}^{\mathrm{n}_{\mathrm{n}}} \sum_{\mathrm{t}=1}^{\mathrm{n}_{\mathrm{t}}} \mathrm{q}_{\mathrm{n}}^{\mathrm{t}} *\left(\mathrm{H}_{\mathrm{n}}^{\mathrm{t}}-\mathrm{Z}_{0}\right)^{*} \Delta_{\mathrm{t}}\right)_{\mathrm{d}=\frac{\text { AC }}{\text { TOT }}}^{*} \alpha-\mathrm{E}_{\mathrm{MIN}}
$$

Where:

- $\quad \mathrm{H}_{\mathrm{n}}^{\mathrm{t}}$ is the node head $(\mathrm{m})$ at time $\mathrm{t}$;

- $\mathrm{n}_{\mathrm{t}}$ is the number of the time interval;

- $\mathrm{n}_{\mathrm{n}}$ is the number of nodes;

- $\mathrm{d}=\mathrm{AC} / \mathrm{TOT}$ refers to the simulation without water losses (i.e., defining a demand multiplier as the percentage of authorized consumption provided by the water balances);

- $\mathrm{q}_{\mathrm{n}}^{\mathrm{t}}$ is the consumption of the node $\left(\mathrm{m}^{3} / \mathrm{s}\right)$ at time $\mathrm{t}$;

- $\Delta \mathrm{t}$ is the time variation.

Part of the total energy supplied is dissipated through friction in the pipelines, valves, or pumps. This dissipated energy may also be divided between authorized consumption and water losses. The friction energy of the pipe associated with the authorized consumption is calculated through Equation 08.

$$
\mathrm{E}_{\mathrm{DISS}}=\gamma^{*}\left(\sum_{\mathrm{i}=1}^{\mathrm{n}_{\mathrm{p}}} \sum_{\mathrm{t}=1}^{\mathrm{n}_{\mathrm{t}}} \mathrm{q}_{\mathrm{i}}^{\mathrm{t}} * \mathrm{~J}_{\mathrm{i}}^{\mathrm{t}}{ }^{*} \mathrm{~L}_{\mathrm{i}}^{*} \Delta_{\mathrm{t}}\right)_{\mathrm{d}=\frac{\text { AC }}{\text { TOT }}}
$$

Where:

- $\quad \mathrm{q}_{\mathrm{i}}^{\mathrm{t}}$ is the flow the pipe $\left(\mathrm{m}^{3} / \mathrm{s}\right)$ at time $\mathrm{t}$;

- $\quad \mathbf{J}_{\mathrm{i}} \mathrm{i}_{\mathrm{i}}$ the loss of capacity the unit $(\mathrm{m} / \mathrm{m})$ at time $\mathrm{t}$;

- $\quad \mathrm{N}_{\mathrm{p}}$ is the number of pumps;

- $\quad \mathrm{L}_{\mathrm{i}}$ is the length of the pipe $(\mathrm{m})$. 
To obtain the pipeline friction associated with the water losses, it is necessary to perform a simulation with a demand multiplier $\mathrm{d}=1$ and subtract the results of the dissipated energy associated with the authorized consumption, as seen in Equation 09.

$$
\mathrm{E}_{\mathrm{DISSWL}}=\mathrm{\gamma}^{*}\left(\sum_{\mathrm{i}=1}^{\mathrm{n}_{\mathrm{p}}} \sum_{\mathrm{t}=1}^{\mathrm{n}_{\mathrm{t}}} \mathrm{q}_{\mathrm{i}}^{\mathrm{t}} * \mathrm{~J}_{\mathrm{i}}^{\mathrm{t}} * \mathrm{~L}_{\mathrm{i}}^{*} \Delta_{\mathrm{t}}\right)_{\mathrm{d}=1} * \alpha-\mathrm{E}_{\mathrm{DISS}}
$$

The energy loss at the valves associated with the authorized consumption may be calculated through Equation 10. The energy loss at the valves associated with water losses may be calculated by Equation 11 .

$$
\begin{gathered}
\mathrm{E}_{\text {DISSVA }}=\gamma^{*}\left(\sum_{\mathrm{i}=1}^{\mathrm{n}_{\mathrm{v}}} \sum_{\mathrm{t}=1}^{\mathrm{n}_{\mathrm{t}}} \mathrm{q}_{\mathrm{i}}^{\mathrm{t} *} \Delta \mathrm{H}_{\mathrm{i}}^{\mathrm{t}} * \Delta_{\mathrm{t}}\right)_{\mathrm{d}=\frac{\text { AC }}{\text { TOT }}}^{*} \alpha \\
\mathrm{E}_{\text {DISSVAWL }}=\gamma^{*}\left(\sum_{\mathrm{i}=1}^{\mathrm{n}_{\mathrm{v}}} \sum_{\mathrm{t}=1}^{\mathrm{n}_{\mathrm{t}}} \mathrm{q}_{\mathrm{i}}^{\mathrm{t} *} \Delta \mathrm{H}_{\mathrm{i}}^{\mathrm{t}} * \Delta_{\mathrm{t}}\right)_{\mathrm{d}=1} * \alpha-\mathrm{E}_{\text {DISSVA }}
\end{gathered}
$$

Where:

- $\mathrm{q}_{\mathrm{i}}^{\mathrm{t}}$ is the water flow $\left(\mathrm{m}^{3} / \mathrm{s}\right)$ through the valve at time $\mathrm{t}$;

- $\Delta \mathrm{H}_{\mathrm{i}}{ }^{\mathrm{t}}$ is the pressure drop $(\mathrm{m})$ at time $\mathrm{t}$.

The energy dissipated at the pumping stations may be calculated through Equations 12 and 13 .

$$
\begin{aligned}
& \mathrm{E}_{\text {DISSPSAC }}=\sum_{\mathrm{S}=1}^{\mathrm{n}_{\mathrm{S}}} \mathrm{E}_{\mathrm{S}} *\left(1-\eta_{\mathrm{S}}\right) * \frac{\forall_{\mathrm{AC}}}{\forall_{\text {TOT }}} \\
& \mathrm{E}_{\text {DISSPSWL }}=\sum_{\mathrm{S}=1}^{\mathrm{n}_{\mathrm{S}}} \mathrm{E}_{\mathrm{S}} *\left(1-\eta_{\mathrm{S}}\right) * \frac{\forall_{\mathrm{WL}}}{\forall_{\text {TOT }}}
\end{aligned}
$$

Where:

- $\eta_{S}$ is the efficiency of the pump motor set;

- $E_{S}$ is the spent energy of the pump motor set;

- $\quad \mathrm{ns}$ is the number of pumps in the system;

- $\quad \forall_{P A}$ is the water loss volume at the pumping station.

The energy associated with the water losses at the consumption nodes includes the apparent losses that correspond to unauthorized consumption and measurement errors by the consumer. It also includes the real losses, which correspond to the real water losses in the water network in the entire system. Through Equation 14, one may calculate the energy associated with the water losses. 


$$
\mathrm{E}_{\text {DISSNO }}=\gamma^{*}\left(\sum_{\mathrm{n}=1}^{\mathrm{n}_{\mathrm{n}}} \sum_{\mathrm{t}=1}^{\mathrm{n}_{\mathrm{t}}}\left(\mathrm{q}_{\mathrm{n}}^{\mathrm{t}} *\left(\mathrm{H}_{\mathrm{n}}^{\mathrm{t}}-\mathrm{z}_{\mathrm{O}}\right)\right)_{\mathrm{d}=1}\right) * \Delta \mathrm{T}-\mathrm{E}_{\mathrm{MIN}}-\mathrm{E}_{\text {SUR }}
$$

To evaluate the energy efficiency, it is necessary to calculate the performance indicators such as specific energy consumption per volume of pumped water $\left(\mathrm{kWh} / \mathrm{m}^{3}\right)$ (ISO, I. O. f. S. 2015) or standardized energy consumption $\left(\mathrm{kWh} / \mathrm{m}^{3} / 100 \mathrm{~m}\right)$ (Alegre et al., 2006).

The specific energy consumption indicator is much used but does not allow comparing the efficiency of the pump in systems with different topographies; in turn, the standardized energy consumption only serves the efficiency of the pumping systems, not providing specific information about the global efficiency of the system, and also does not allow monitoring the impact of different alternative solutions if they have no direct impact on pumping stations (Mamade et al., 2017).

Mamade et al. (2017) proposed three performance indicators (E1, E2, and E3) to assess the energy efficiency of the system better. Such indicators are based on the concepts of minimum energy and surplus energy (Alegre et al., 2006).

Indicator E2 (Equation 15) represents the theoretical potential for energy reduction by volume of authorized consumption. E2 always has a positive value; the lower, the better. Since the denominator is the authorized consumption, this indicator reflects the impact of the leakage control measures and may also be evaluated in terms of natural input energy (E2 (natural)) and shaft input energy (E2 (shaft)), according to Equations 16 and 17.

$$
\begin{gathered}
E 2=\left(E_{T O T}-E_{M I N}\right) / \nabla_{A C}\left(\mathrm{kWh} / \mathrm{m}^{3}\right) \\
E 2(\text { natural })=\left(E_{N}-E_{M I N}\right) / \forall_{A C}\left(\mathrm{kWh} / \mathrm{m}^{3}\right) \\
E 2(\text { shaft })=\left(E_{S I}-E_{M I N}\right) / \forall_{A C}\left(\mathrm{kWh} / \mathrm{m}^{3}\right)
\end{gathered}
$$

Indicator E3 (Equation 18) represents a ratio of the theoretical surplus energy supplied to the system to the minimum energy necessary and may be evaluated in terms of surplus energy due to the operation and layout of the network (E3 (network)) (Equation 19), or improvement potential of the pumps is given by the evaluation of E3 with the energy dissipated at the pumps (E3 (pumps)) (Equation 20). The improvement potential for water losses is given by assessing E3 with the energy associated with water losses (E3 (losses)) (Equation 21).

$$
\begin{gathered}
E 3=\left(E_{\text {TOT }}-E_{\text {MIN }}\right) / E_{\text {MIN }} \\
E 3(\text { system })=\left(E_{\text {SUR }}+E_{\text {DISS }}+E_{\text {DISSVA }}\right) / E_{\text {MIN }} \\
E 3(\text { pump })=\left(E_{\text {DISSPSAC }}\right) / E_{\text {MIN }} \\
\text { E3 (losses })=\left(E_{\text {WL }}\right) / E_{\text {MIN }}
\end{gathered}
$$


The energy balance scheme by Mamade et al. (2017) and the indicators are applied to this work in a simplified manner.

For the complete evaluation for the critical analysis areas, it was necessary to assess the complete system, from reservoir R3, the lift station in $\mathrm{R} 3$, reservoir $\mathrm{R} 4$, and the water distributed to all the nodes in the studied sector, since the simplified evaluation was applied between R3 and R4.

We used the hydraulic model of the EPANET elaborated by Goulart (2015) and adapted to the present work, as well as the algorithm developed by CERIS, Instituto Superior Técnico, Universidade de Lisboa, Portugal, with software iPerdas and figure 03 illustrates the model used to apply the complete energy balance of the studied sector.

Figure 3. Hydraulic Model for the Complete Evaluation.

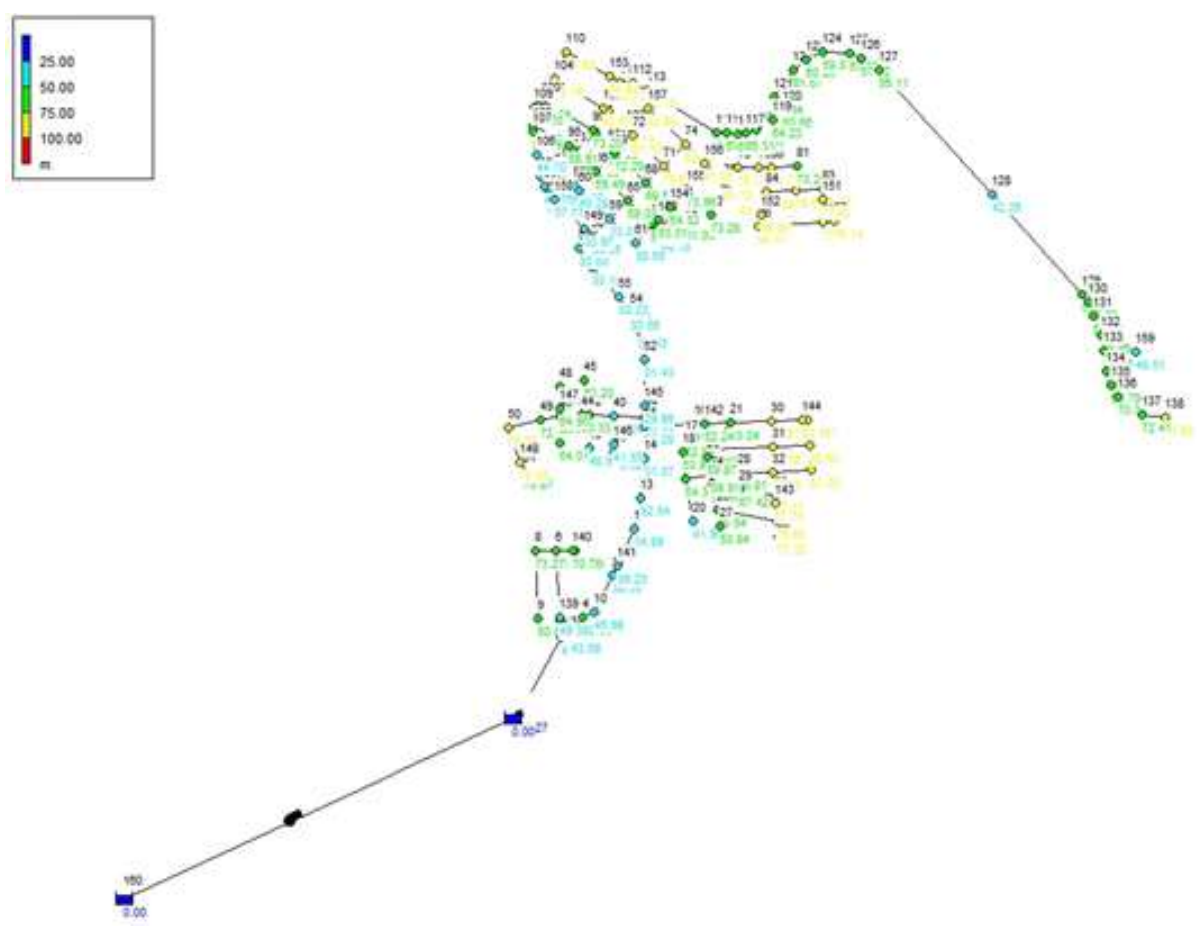

Source: Adapted from Goulart (2015).

\section{Results and Discussion}

Figure 04 presents the surplus energy per authorized consumption (E2) divided by the components of natural input energy and shaft input energy. The mean E2 weighted by the authorized consumption is $0.52578 \mathrm{kWh} / \mathrm{m}^{3}$. Indicator E2 indicates the theoretical potential for energy reduction by volume of authorized consumption. The lower the value of this indicator is, the better the system efficiency. 
Figure 4. Total energy at R3.

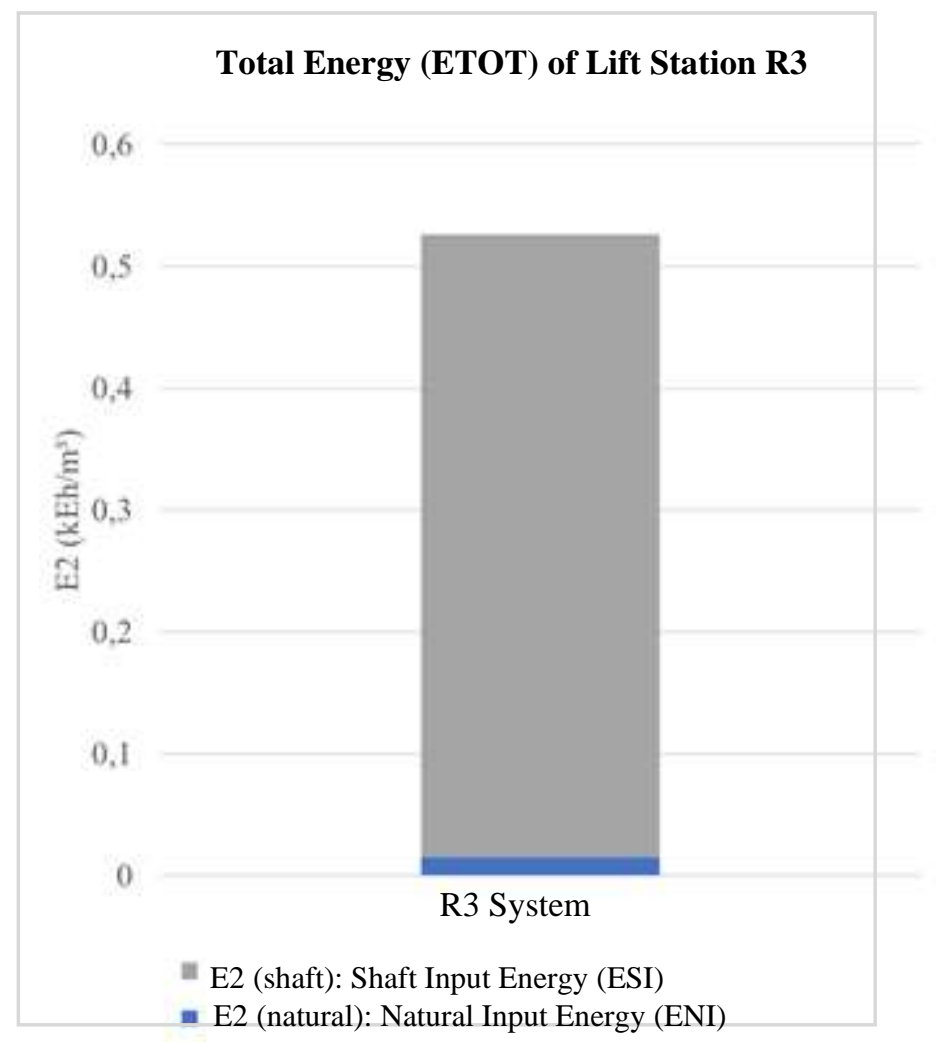

Source: Authors.

Figure 05 presents the ratio of the maximum surplus energy (E3) to the components of energy dissipated in the pipelines (system), pumps, and losses. The mean E3 weighted by the minimum energy is 1.439, meaning that this surplus energy represents 1.439 times the minimum energy required. The value of indicator E3 must be the smallest possible; the improvement potential of the pump is given by the evaluation of E3 with the energy dissipated in the pumps. 
Figure 5. Indicator applied to R3.

\section{Indicator E3}

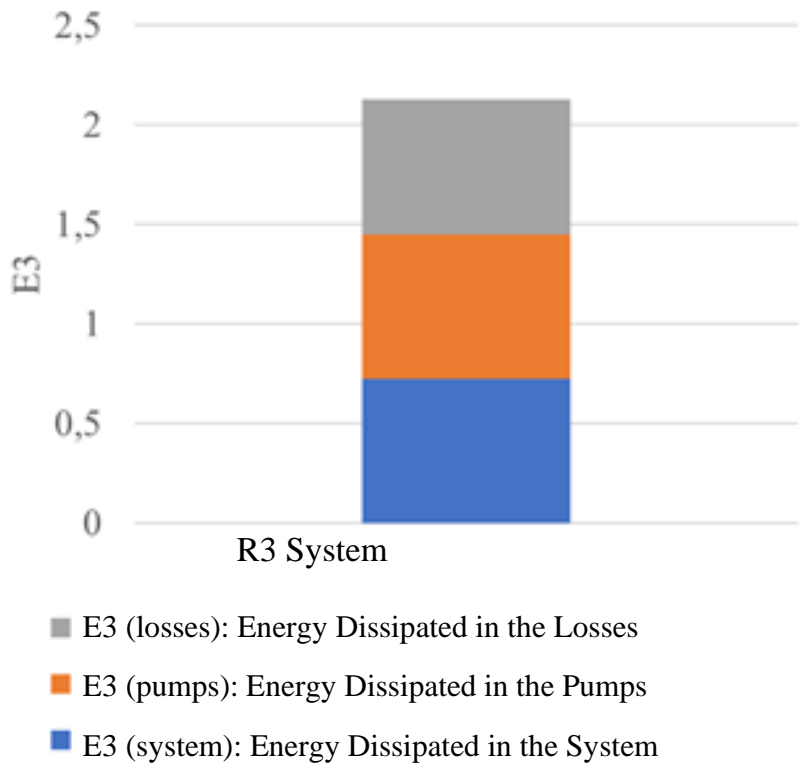

Source: Authors.

The global results also show a significant energy saving potential: $40 \%$ through water loss reduction, $30 \%$ for changes in the network operation and layout, and $30 \%$ for pipeline inefficiency reduction.

The water not stemming from the revenue represents $27.73 \%$ of the input volume. The result of the complete energy balance for the studied sector based on the methodology by Mamade et al. (2017) and adapted for the analysis is presented in Table 06. 
Table 6. Energy Balance based on the Methodology by Mamade (2017) - Simplified evaluation.

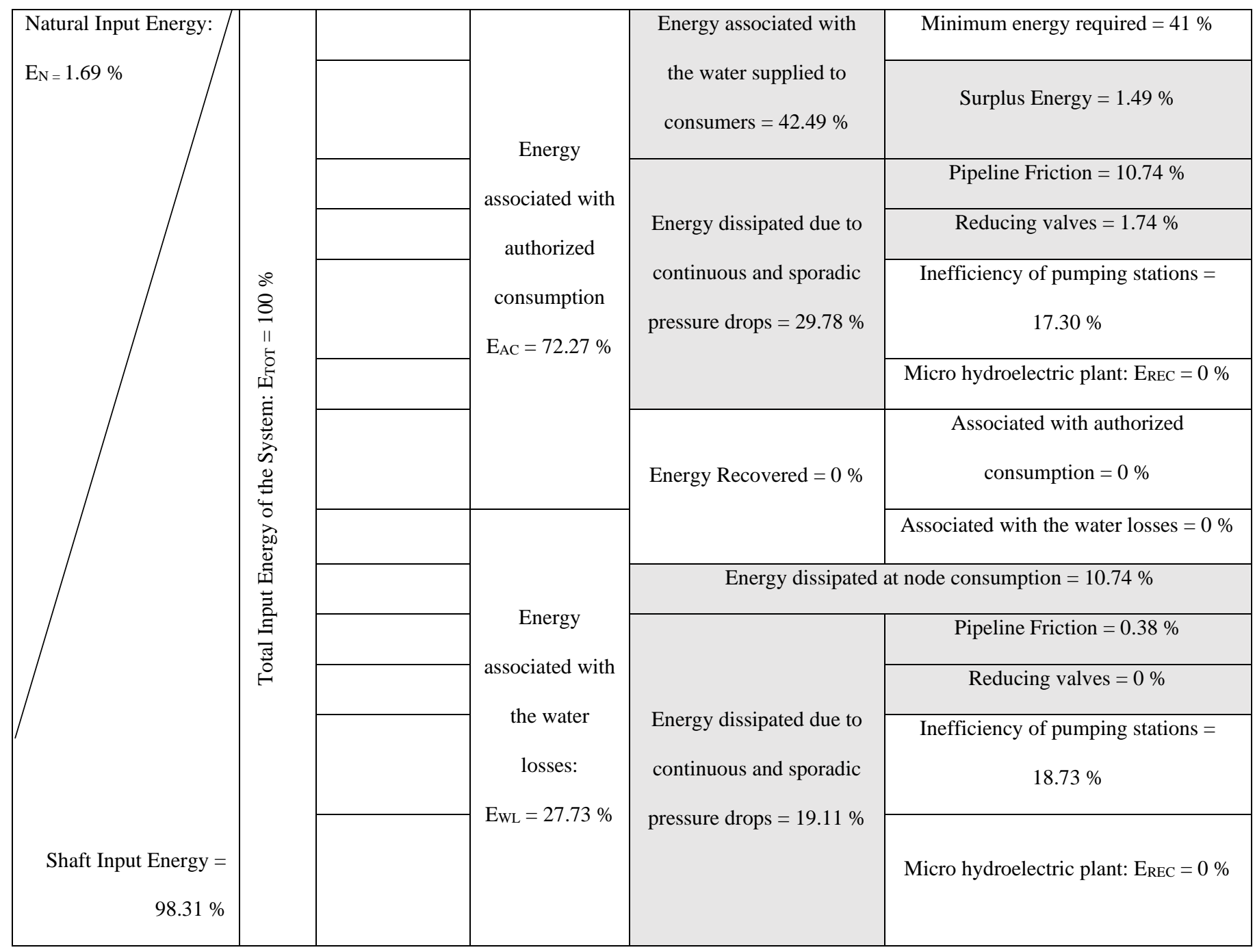

Source: Authors.

Simulations were carried out considering the daily consumption patterns, with a time interval of one minute. The results show that approximately $72.27 \%$ of the energy is associated with authorized consumption and $27.73 \%$ with water losses. Of the $72.27 \%$ of energy, around $42.49 \%$ is delivered to reservoir R4, and the rest is lost or dissipated. In this case, actions to reduce the water losses at the consumption nodes and lower the pipeline friction may be more effective than acting on improving pump efficiency.

The application of the simplified evaluation in the studied sector of the AWSS showed that the system uses more than double the minimum energy required by its consumers, which reveals a significant energy saving potential: $27.73 \%$ through water loss reduction, $29.78 \%$ through changes in the network operation and layout, and $42.03 \%$ through pump inefficiency reduction. The result of the complete energy balance for the studied sector based on the methodology by Mamade et al. (2017) and adapted for the analysis is presented in Table 07. 
Table 7. Energy Balance based on the Methodology by Mamade et al. (2017) - Complete evaluation.

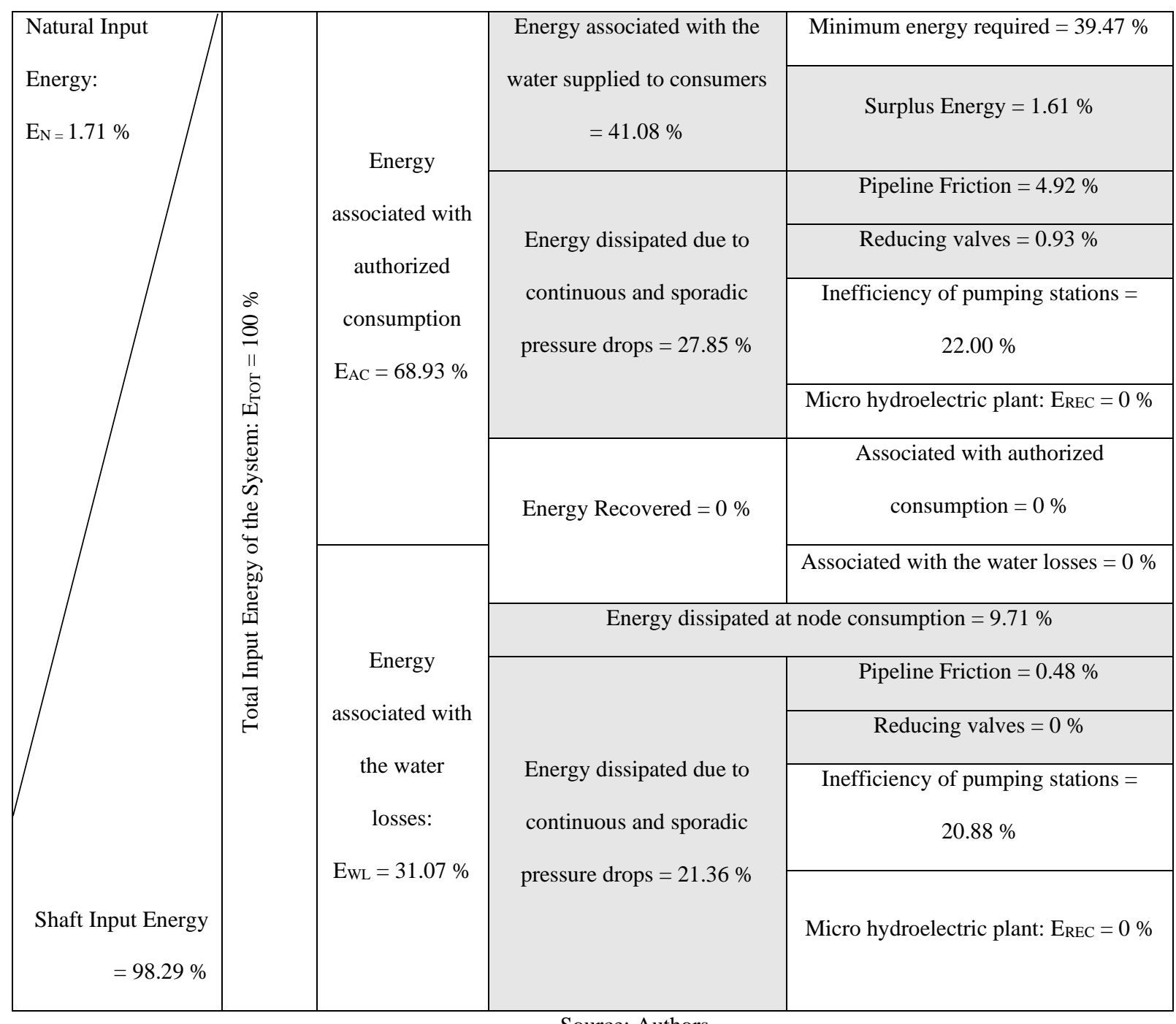

Considered for this model were reservoir R3, pump motor sets B1 and B2, reservoir R4, and the consumption nodes of the studied sector, delimiting the system.

Simulations were carried out considering the daily consumption patterns, with a time interval of one minute. The results show that approximately $68.93 \%$ of the energy is associated with authorized consumption and $31.07 \%$ with water losses. Of the $68.93 \%$ of energy, around $39.43 \%$ are effectively delivered to the consumers, and the rest is lost or dissipated in the network.

\section{Conclusion}

In the case study with the AWSS of the chosen city, the pump efficiencies operate far below the original pump. Sets B1 and B2 with $27 \%$ and $18 \%$ less, respectively. With this, it becomes clear that pump maintenance has been inefficient.

The insufficient pressures, compared with the original pump, characterize that, internally, the pumps have issues, i.e., the wearing rings need to be replaced and the rotor of each pump may be damaged or worn, requiring corrective maintenance or even replacement.

The pressure and pumped flow in Set B1 did not present a divergent behavior since the pressure as a function of the flow has an inversely proportional behavior, i.e., an increase in flow is accompanied by a decrease in pressure. However, in Set 
B2, there was a more considerable pressure drop in the early hours.

The adaptation of the methodology by Mamade et al. (2017) allowed calculating the energy balance of the system and some important indicators to evaluate the energy efficiency of the AWSS. The surplus energy per authorized consumption (E2) divided by the components of natural input energy and shaft input energy resulted in the value of $0.52578 \mathrm{kWh} / \mathrm{m}^{3}$. The ratio of the maximum surplus energy (E3) to the components of energy dissipated in the pipelines (system), pumps, and losses was 1.439 , meaning that this surplus energy represents 1.439 times the minimum energy required.

The energy efficiency indicator EEI for the studied sector resulted in a value of $17.38 \%$, demonstrating that the system is not efficient, and decisions must be made and measures must be taken aiming to improve this performance.

The application of the simplified evaluation in the studied sector of the AWSS showed that the system uses more than double the minimum energy required by its consumers, which reveals a significant energy saving potential: $27.73 \%$ through water loss reduction, $29.78 \%$ through changes in the network operation and layout, and $42.03 \%$ through pump inefficiency reduction.

The diagnostic provided by the complete energy balance allows understanding which components are responsible for the greatest energy losses in the system. In general terms, the high pump inefficiencies require reevaluating the needs of a pumping station through the study of new ways to supply a given area less intensively in terms of energy or through redesigning the system, namely:

- The surplus energy in the nodes requires pressure management;

- The high pipeline friction rate indicates that the rehabilitation and/or substitution of the piping must occur;

- $\quad$ The considerable pressure drop in the valves may indicate an energy recovery potential;

- The high energy loss in the consumption nodes requires an analysis more focused on the water balance components of the real and apparent losses.

This paper is another important step in the sense of correlating water and energy in AWSSs, as well as researching and quantifying the impact of integrated solutions on the general efficiency of a water supply system. Therefore, a judicious study must be carried out, aiming to achieve the energy efficiency of the system with the correct maintenance to increase the efficiency of the ensemble.

\section{Acknowledgments}

Acknowledgment: The authors thanks FINEP Redecope Project - MCT (Ref. 0983/10) - Ministry of Science and Technology entitled "Development of efficient technologies for hydro management efficiency in water supply systems' program "Pesquisador Mineiro" Fapemig for the PPM - 00755-16 besides thanking NUMMARH - Nucleus of Modeling and Simulation in Environment and Water Resources and systems of unified. Thanks to CAPES for the master's scholarship number 1764063 to the author "Alex Takeo Yasumura Lima Silva".

\section{References}

ABES. (2013). Perdas em sistemas de abastecimento de água: diagnóstico, potencial de ganhos com sua redução e propostas de medidas para o efetivo combate. Sumário Executivo. http://www.abes-sp.org.br/arquivos/perdas_resumo.pdf

Ahopelto, S. \& Vahala, R. (2020). Cost-benefit analysis of leakage reduction methods in water supply networks. Water, 12 (1), 195. doi:10.3390/w12010195 Alegre, H. et al. (2017). Performance indicators for water supply services. London: IWA Publishing.

ANA. (2018). Abastecimento Urbano de Água. http://www.ana.gov.br/

Andrade, M. R. (2016). Balanço hidroenergético de sistema de distribuição de água aplicado a um setor do município de Cambuí - MG. Master's Thesis. https://repositorio.unifei.edu.br/xmlui/handle/123456789/494 
Aznar-Sánchez, J. A. et al. (2018). Mining waste and its sustainable management: Advances in worldwide research. Minerals, 8 (7), 284. doi: $10.3390 / \min 8070284$

Baleta, J. et al. (2019). Integration of energy, water and environmental systems for a sustainable development. Journal of cleaner production, 215 (1), $1424-$ 1436. doi:10.1016/j.jclepro.2019.01.035

Bieber, N. et al. (2018). Sustainable planning of the energy-water-food nexus using decision making tools. Energy Policy, 113 (1), $584-607$. doi:10.1016/j.enpol.2017.11.037

Britton, T. C. et al. (2013). Smart metering: Enabler for rapid and effective post meter leakage identification and water loss management. Journal of Cleaner Production, 54 (1), 166-176. doi:10.1016/j.jclepro.2013.05.018

Cantele, S. et al. (2018). A new framework for assessing the sustainability reporting disclosure of water utilities. Sustainability, 10 (2), 433. doi:doi.org/10.3390/su10020433

Chini, C. M., \& Stillwell, A. S. (2018). The state of US urban water: data and the energy-water nexus. Water Resources Research, 54 (3), 1796-1811. doi:

Coelho, B. \&, Andrade-Campos, A. (2014). Efficiency achievement in water supply systems - A review. Renewable and Sustainable Energy Reviews, 30 (2), 59-84, 2014. doi:10.1016/j.rser.2013.09.010

Goulart, T. D. C. (2015) Estudos de Aprimoramento de Algoritmo de Calibração e Aplicação em Rede de Distribuição de Água de Cambuí (MG). Master's Thesis. https://repositorio.unifei.edu.br/xmlui/handle/123456789/147

Krueger, E. H. et al. (2020). Balancing security, resilience, and sustainability of urban water supply systems in a desirable operating space. Environmental Research Letters, 15 (3), 22. doi:10.1088/1748-9326/ab6c2d

Lambert, A. \&, Hirner, W. (2000). Losses from Water Supply Systems: Standard Terminology and Recommended Performance Measures. IWA the blue pages, $10(3), 1-13$.

Lee, S. et al. (2021). Setting future water rates for sustainability of a water distribution system. Journal of Water Resources Planning and Management, 147 (2), 13. doi:10.1061/(ASCE)WR.1943-5452.0001313

Luna, T. et al. (2019). Improving energy efficiency in water supply systems with pump scheduling optimization. Journal of cleaner production, 213 (3), $342-$ 356. doi: 10.1016/j.jclepro.2018.12.190

Mamade, A. et al. (2017). A comprehensive and well tested energy balance for water supply systems. Urban Water Journal, 14 (8), 853-861. doi:10.1080/1573062X.2017.1279189

Mamade, A. et al. (2018a). Assessing the Impact of Network Layout on Energy Efficiency, Water Losses and Water Quality in Water Supply. WDSA/CCWI Joint Conference Proceedings. Retrieved Sep 21, from https://ojs.library.queensu.ca

Mamade, A. et al. (2018b). Top-down and bottom-up approaches for water-energy balance in Portuguese supply systems. Water, 10 (5), 577. doi: $10.3390 /$ w10050577

Mutikanga, H. E. et al. (2009). Water loss management in developing countries: Challenges and prospect. Journal - American Water Works Association, 101 (12), 57-68. doi:10.1002/j.1551-8833.2009.tb10010.x

Oikonomou, K. \& Parvania, M. (2018). Optimal coordination of water distribution energy flexibility with power systems operation. IEEE Transactions on Smart Grid, 10 (1), 1101-1110. doi:10.1109/TSG.2018.2824308

Razmjoo, A. et al. (2020). The main role of energy sustainability indicators on the water management. Modeling Earth Systems and Environment, 6 (3), 14191426. doi:10.1007/s40808-020-00758-1

Rodrigues, R. C. (2012). Análise do desempenho hidroenergético de sistemas de abastecimento de água do município de Marabá/PA. Master's Thesis. http://repositorio.ufpa.br/jspui/handle/2011/3546

Sgroi, M. et al. (2018). Feasibility, sustainability and circular economy concepts in water reuse. Current opinion in environmental Science \& Health, 2 (4), 2025. doi:10.1016/j.coesh.2018.01.004

Song, M. et al. (2018). Water resources utilization efficiency and influence factors under environmental restrictions. Journal of Cleaner Production, 184 (5), 611-621. doi:10.1016/j.jclepro.2018.02.259 